September 2006

\title{
When Persecution Bleeds into Mass Murder: The Processive Nature of Genocide
}

Uğur Ü. Üngör

Follow this and additional works at: https://digitalcommons.usf.edu/gsp

\section{Recommended Citation}

Üngör, Uğur Ü. (2006) "When Persecution Bleeds into Mass Murder: The Processive Nature of Genocide," Genocide Studies and Prevention: An International Journal: Vol. 1: Iss. 2: Article 7.

Available at: https://digitalcommons.usf.edu/gsp/vol1/iss2/7

This Articles is brought to you for free and open access by the Open Access Journals at Digital Commons @ University of South Florida. It has been accepted for inclusion in Genocide Studies and Prevention: An International Journal by an authorized editor of Digital Commons @ University of South Florida. For more information, please contact digitalcommons@usf.edu. 


\title{
When Persecution Bleeds into Mass Murder: The Processive Nature of Genocide
}

\author{
Uğur Ü. Üngör \\ Center for Holocaust and Genocide Studies, Amsterdam
}

In the rapidly developing historiography of the Armenian Genocide, the processive character of pre-genocidal persecutions has received less attention than the genocidal process itself. This article treats the persecution of Ottoman Armenians as a cumulative process leading up to a mass-murder campaign in the summer of 1915. It addresses the evolution of CUP policy toward the Armenians through the prism of escalating persecution and the relationship between center and periphery. In order to illustrate the concrete implementation of this process, the province of Diyarbekir will serve as an example to clarify the history of the persecutions.

\section{Introduction}

This article will address the evolution of CUP policy toward the Armenians through the prism of escalating persecution and the relationship between center and periphery, within the context of the development of general Ottoman population policies between 1913 and 1915. In this period, the Ottoman Empire was under the rule of the Committee of Union and Progress (Ittihad ve Terakki Cemiyeti), or CUP. From 1914 on, a small but radical faction within this semi-official political party, ${ }^{1}$ having seized government power, launched empire-wide campaigns of persecution, involving mass deportation, forced assimilation, and genocidal destruction of various ethnic communities. Hundreds of Arab, Armenian, Kurdish, Syriac, and other communities were affected and suffered heavy losses as a result of these forced relocations and persecutions, which combined with wartime famines due to corruption, failed harvests due to deportations, and the outbreak of contagious diseases to kill millions of human beings. The CUP put its policies into practice for the sake of a thorough ethno-religious homogenization of the empire, resulting in the establishment of a Turkish nation-state in 1923. In subsequent decades, processes of social engineering went on, as many CUP potentates remained influential and continued to formulate and implement new policies of demographic engineering in the Turkish Republic.

In his book on ethnic cleansing, Norman Naimark notes that "ethnic cleansing bleeds into genocide." ${ }^{2}$ More recently, Jacques Sémelin has offered a painstaking analysis of how precisely this occurs: born out of a political crisis, radical regimes launch persecutory measures that can subsequently escalate into a genocidal process. ${ }^{3}$ Scholarly research on the Holocaust has treated this process in great detail and with sound lucidity. ${ }^{4}$ In the rapidly developing historiography of the Armenian Genocide, the processive character of these pre-genocidal persecutions has received less attention than the genocidal process itself. ${ }^{5}$ The same may be said of the postgenocidal persecutions and violence. ${ }^{6}$ This article will address the persecution of 
Ottoman Armenians as a cumulative process leading up to the mass-murder campaign of the bloody summer of 1915. The province of Diyarbekir will serve as an example to illustrate this process.

The Ottoman Empire was organized into provinces (vilayet) with governors (vali), districts (sancak or liva) with district governors (mutasarrlf), counties (kazâ) with mayors (kaymakam), and communes (nahiye) with directors (müdür). Diyarbekir was a relatively large province $\left(42,100 \mathrm{~km}^{2}\right)$ locked between the Euphrates in the west, the Tigris in the east, the plateau in the north, and the desert in the south. Its continental climate ensured mild winters and extremely hot summers, which at times paralyzed social life. Historically, Diyarbekir was an administrative center; it had been the headquarters of the sixteenth-century governorship (beylerbeylişi) from which large parts of eastern Turkey were ruled. ${ }^{7}$ On the eve of World War I, the Second Army was stationed in Diyarbekir city, which also harbored a court-martial and one of the largest prisons of the Ottoman Empire. Although there were regional variations in the economic conditions of the province, generally it thrived because of its favorable location on the ancient Silk Road. ${ }^{8}$ There were copper mines in Maden county, and the border regions with Bitlis province were known to be rich in oil, though no large-scale steps had been taken to exploit either resource. Like the rest of the empire, Diyarbekir was a pre-industrial region where subsistence farming and cyclic pastoralism were dominant economic occupations for peasants and nomads in the countryside. ${ }^{9}$

Diyarbekir province boasted a formidable diversity of ethnic and religious groups, whether small or large, scattered or concentrated, urban or rural. Turkish-speaking Muslims constituted the majority in urban residential areas because they had occupied most administrative positions for a long time. Armenians inhabiting the cities made their livings as merchants or craftsmen, and in most bazaars the majority of tradesmen were indeed Armenian. Some of these were quite prosperous, imbued with the privilege of having family members abroad and being active in politics. But most of Diyarbekir's Armenians were peasants organized in large extended families (gerdastans) in villages, most specifically in the Lice, Silvan, Beşiri, and Palu districts. ${ }^{10}$ The Kurdish population of the province can be divided in several categories: tribal versus non-tribal Kurds and (semi-) nomadic versus sedentary. The dozens of large and powerful Kurdish tribes (eşîra) in the region were generally commanded by chieftains and de facto controlled extensive territories. Many were able to mobilize thousands, sometimes tens of thousands, of mounted warriors, often to combat each other in pursuit of power, honor, and booty. Non-tribal Kurds could be powerless peasants (kurmanc) or Kurds from noted clergy families (meşayih). It is important to point out that most peasants, irrespective of ethnic or religious background, paid tribute and taxes to Kurdish chieftains and sometimes to other landlords. ${ }^{11}$ The mere 1,000 Jews of Diyarbekir province owned one small synagogue and were generally an inconspicuous ethnic group among the much larger Christian and Muslim populations. They engaged mainly in small-scale trade and some horticulture. ${ }^{12}$ The Yezidis, a Kurdish-speaking monotheist people, inhabited villages in the southeastern regions of the province. Ottoman state discrimination and oppression against them pushed them into a marginal social status, as a result of which they frequently engaged in organized brigandry. ${ }^{13}$ Most of the province's Arabs lived in Mardin and in the villages in and around Midyat, numbering no more than several thousand. ${ }^{14}$ The Syriacs, an embracing denomination including all Aramaic-speaking Syrian-Orthodox, SyrianProtestant, Syrian-Catholic, Nestorian, and Chaldean Christians, inhabited many 


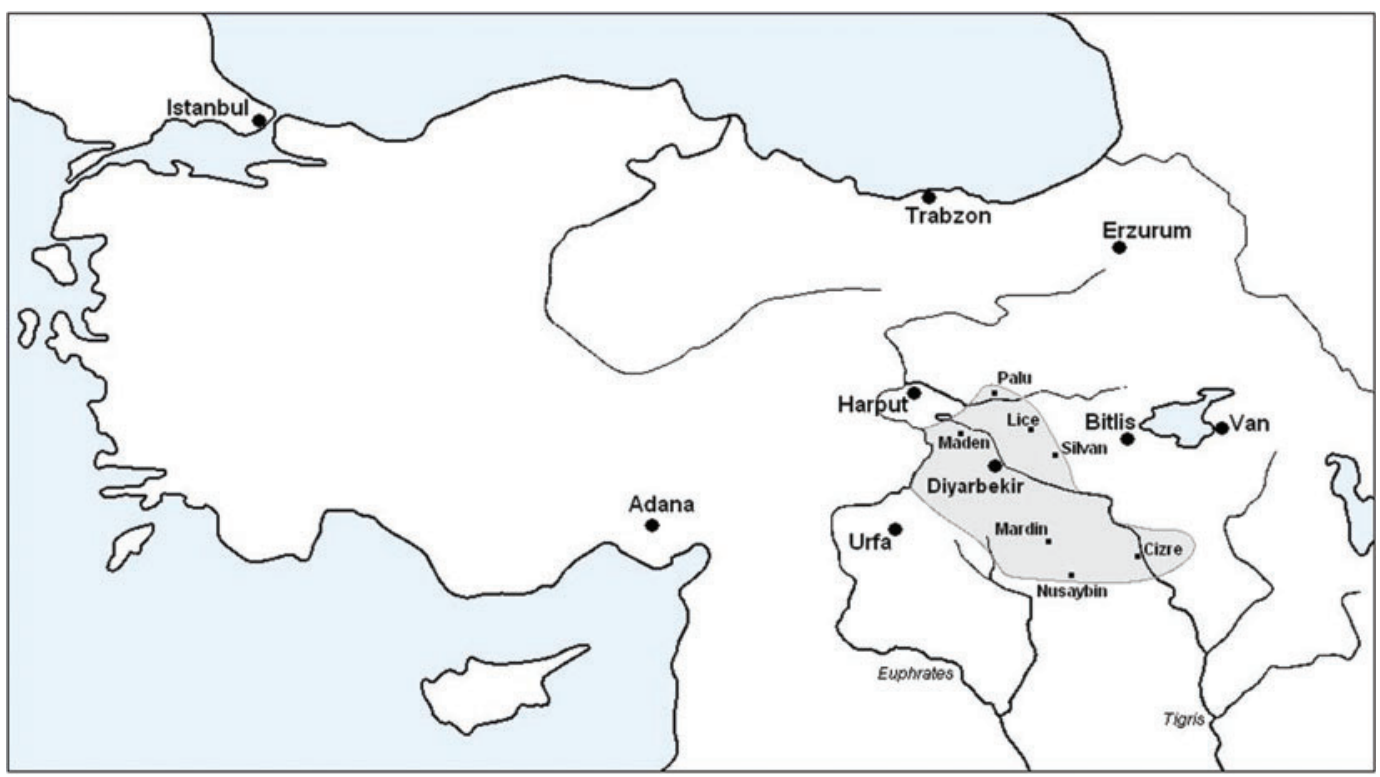

Figure 1: A bird's-eye view of Diyarbekir province

villages but especially the southeastern parts of the province. The mountainous region around Midyat, also known as Tur Abdin, was a Syriac stronghold, with dozens of often exclusively Syriac villages. ${ }^{15}$ Though these were only some of the ethnic and religious groups in the province, because of the absence of reliable demographic data it is very difficult to come to quantitative grips with even these. In general, it seems reasonable to contend that approximately one-third of the province's population was Christian and approximately two-thirds were Muslim. ${ }^{16}$

The heterogeneous ethnic and social composition of the population of Diyarbekir province was fueled by two additional intricacies: vagueness of identity and competing loyalties. Identities were ethnic, not homogeneous-national in the modern sense. This complex social reality of considerable overlap and indistinctness of ethnic delineation defies simple categorizations, as many people lived at the margins of ethnicity. For example, the Armenians of Mardin spoke Arabic and were mostly Catholic; many Armenian villagers spoke Kurdish and adhered to a range of rural superstitions, whereas the Armenians of Diyarbekir city spoke a local Armenian dialect and were close to the official Apostolic church. ${ }^{17}$ Tribal cleavages and loyalties were another issue. Even though Kurdish tribes had hereditary chieftains of Kurdish descent, they treated their Muslim and non-Muslim subjects alike: religious interests and loyalties were subordinated to tribal ones.

It is crucial to bear these anthropological subtleties in mind before engaging in any historical analysis of this wide spectrum of peoples. Essentialist notions of homogeneous national entities engaging in collective action or perpetual conflict are utterly ahistorical and need to be subjected to thorough deconstructionist criticism. The same is true for rosy images of a peaceful society in pre-nationalist conditions, basking in multicultural coexistence. ${ }^{18}$ Nevertheless, it is possible to state that the absence, or very feeble presence, of the state and its monopoly of violence in rural areas allowed for the maintenance of many conflicts, whether tribal or ethno-social. 
Therefore, living conditions were relatively insecure, with arbitrary exertion of (mortal) violence by certain powerful tribes and state agents. This insecurity only added to the general atmosphere of distrust and generated anxiety and vulnerability among the inhabitants of the province.

\section{Preambles: War and Surveillance}

The Committee of Union and Progress had not been idle in the provinces before the war. The first CUP office in Diyarbekir, for example, was opened on 23 July 1908 by Ziyâ Gökalp (1876-1924), who was a native of the region and became its representative on the party's Central Commitee in 1910. ${ }^{19}$ Gökalp began publishing the newspaper Peyman, which adopted a relatively modest tone and emphasized coexistence of the various Ottoman subjects. ${ }^{20}$ After the catastrophic defeats of the Balkan wars, the atmosphere changed as relations polarized. The CUP dictatorship exerted its influence in this province through a network of mainly Kurdish members. The most influential CUP members in Diyarbekir were those related to the wealthy and powerful Pirinççizâde dynasty, who owned large estates in the province, including the rice fields west of Diyarbekir city. ${ }^{21}$

One of their kinsmen was Deputy Aziz Feyzi (1879-1933), who was known for his coarseness and fanatic patriotism. He was the son of Pirinççizâde Arif, who passed away in 1909 and had adhered to the Kurdish Assistance and Progress Society (Kürt Teavïn ve Terakki Cemiyeti). According to a German report, Feyzi had undertaken a study trip to Germany in $1911 .^{22}$ On behalf of many other Kurdish notables, he vehemently protested in the Ottoman parliament against the proposed government plan of expropriating land from Kurdish landowners. Feyzi was a CUP hard-liner. He had held fierce and hostile discussions with an Armenian member of parliament, Vartkes Serengulian (1871-1915), in which he uttered accusatory and pugnacious comments. $^{23}$ He became more and more fanatical in his anti-Armenian views and reportedly had Ohannes Kazazian, a Catholic Armenian from Mardin and his political rival in the elections, assassinated in $1913 .{ }^{24}$ At the outbreak of World War I, the Ottoman civil inspector Mihran Boyadjian traveled to Diyarbekir and encountered an energetic Feyzi on the way:

While travelling, we regularly spoke about politics. In his conversations, Feyzi Bey did not fail to convey certain threats against my coreligionists. "The Armenians," he repeated, with bitterness, "have misconducted with regard to us, during the Balkan wars in our days of distress. The Catholicos of Etchmiadzin, Patriarch Zaven, and Nubar have resorted to foreign intervention; that will cost you dearly, my friend, your future is in danger." 25

Finally he threatened, "You will see now, what it means to demand reforms." ${ }^{26}$ Other CUP sympathizers in Diyarbekir were Pirinççizâde Sıdkı (Tarancı), Yasinzâde Şevki (Ekinci), his brother Yasinzâde Yahya (Ekinci), and Müftüzâde Șeref (Uluğ), among others. $^{27}$

The CUP's policy toward the inhabitants of the eastern provinces varied between containment and repression. On 4 April 1914, one day after the outbreak of the Kurdish rebellion of Bitlis, the Central Committee of the CUP convened to review its policy toward the eastern provinces. Mithat Şükrü (Bleda) pointed out that Russia was gradually tightening its grip on many Kurdish tribes in both the Ottoman Empire and Persia. According to him, another danger was that of Armenian revolutionaries who were awaiting the right opportunity to revolt and could strike at any time. He concocted a divide-and-rule strategy and maintained that on no account should 
Kurdish and Armenian politicians be allowed to unite. He suggested that the CUP should now adopt a more sophisticated stick-and-carrot strategy, enrolling potentially loyal chieftains through rhetoric and bribery while threatening potentially disloyal ones with deportation and incarceration. ${ }^{28}$

The assassination of the Austrian Archduke Franz Ferdinand in Sarajevo on 28 June 1914 stirred up acute international tensions. In the midst of this belligerent atmosphere, the CUP sought to forge alliances with any of the Great Powers in order to help the Ottoman Empire emerge from its diplomatic isolation. Cavid Bey, the pro-British minister of finance, had appealed to Britain in 1911, but, apart from Winston Churchill, the Foreign Office was not interested. ${ }^{29}$ Talât flirted with Russia in May during his trip to the Crimea, where he spoke to Russian Foreign Minister Sergei Sazonov about a possible alliance. The Russians expressed ambivalence in judgment but, in essence, were not interested. ${ }^{30}$ Cemal Pasha approached France but left emptyhanded, lamenting the negotiations with the French as "a huge disappointment." ${ }^{1}$ On 28 July, the same day that Austria-Hungary declared war against Serbia, Enver Pasha proposed a defensive alliance between Imperial Germany and the Ottoman Empire to the German ambassador, Hans Wangenheim. In the next days Grand Vizier Said Halim, Chairman of the Parliament Halil, Enver, and Talât launched intensive negotiations with the Germans behind closed doors. Finally, on 2 August, one day after the German declaration of war against Russia, a written agreement was signed between the two states and a general mobilization was issued by the Ottoman general staff. $^{32}$ The discussions were top secret, and even Cemal Pasha had no knowledge of them. ${ }^{33}$ Three days later Austria-Hungary joined the Turko-German alliance and completed the Central Powers bloc, while Russia, France, and Britain united into the Triple Entente. The Ottoman Empire was now officially allied to Germany and, through the treaty, was inevitably obliged, in this political constellation, to prepare for war. Following the succession of declarations of war in August 1914, the Germans urged the Ottoman minister of war, Enver Pasha, at the end of October to act against Russia. Without a formal declaration of war, Enver ordered the Ottoman navy to bomb the Russian shore immediately, destroying oil tanks and sinking fourteen vessels. ${ }^{34}$ Though few politicians in Istanbul knew of Enver's action, this fait accompli triggered declarations of war by the Triple Entente powers. From 11 November 1914 on, the Ottoman Empire was officially at war with Russia, France, and Britain. ${ }^{35}$

Although World War I immediately engulfed the Ottoman Empire, this was not incidental. The CUP consciously headed in a belligerent direction, and by participating in the war it hoped to find a radical solution to the empire's many problems. From the first day of the war, the CUP's dictatorial rule became more repressive toward all opposition groups. Discordant behavior of internal and external dissenters was dealt with systematically and ruthlessly. The Ottoman Armenian community, suspected of collective disloyalty, was one of the first targets. On 6 September 1914, Talât ordered the Ottoman security apparatus to closely "follow and observe" (takib ve tarassud) the local leadership of Armenian political parties that, according to Talât, had been engaging in "agitation and disturbance" (mefsedet ve melanet) against the notion of Ottomanism all along. ${ }^{36}$ Another perceived problem was the foreign capitulations, a set of legal concessions under which foreign subjects enjoyed privileges such as exemption from Ottoman taxes. The CUP regarded the capitulations as humiliating ${ }^{37}$ and did not wait long to confront them: all capitulations were unilaterally abrogated on 17 September. ${ }^{38}$ The CUP's bold policies not only directly caused the ranks to close, they also led to an indirect form of Turkification, as some government officials 
simply left office voluntarily. On 12 November, Minister of Commerce Süleyman Bustani, a Syriac Protestant, resigned from his cabinet portfolio in protest over what he considered ongoing CUP aggression. ${ }^{39}$ This trend allowed the CUP to fill these administrative positions with nationalists, and, although their Gleichschaltung ${ }^{40}$ was never implemented perfectly, it was sufficient for effective rule.

\section{Brutalizing War, Radicalizing Persecution}

Meanwhile, the mobilization did not go unnoticed in Diyarbekir province. The city streets swarmed with soldiers of the Second Army Corps, led by Ahmet Izzet Pasha, which was partly lodged in large mosques such as the Nebii Mosque. ${ }^{41}$ On 3 November, the mayor of Diyarbekir made a public speech, explaining the conduct of the war to an exclusively Muslim crowd. Upon hearing that the Russian army was pushing into the provinces of Van and Erzurum, the frantic crowd yelled, "Praise to Mohammed! Death to the Russians and their allies!" The non-Muslims of the city, frightened and cautious because of this outbreak of mass rage, did not leave their homes in the following days. ${ }^{42}$ The army began requisitioning goods from the population and drafting men into the army. Daniel Thom, a missionary in Mardin, summarized these acts and wrote that "the Govt. has robbed the city, and the country around, of its men, of its animals, of its money," leaving the people "pennyless, shops all closed." 43 Gradually, the Armenian elite of Diyarbekir was targeted and persecuted. Coinciding with his earlier order, on 29 November Talât ordered the arrest of Thomas Muggerditchian, former interpreter for the British consulate in Diyarbekir. Muggerditchian was accused of espionage for the Entente Powers and was to be court-martialed. ${ }^{44}$ He escaped arrest, fled to Egypt, and subsequently wrote his memoirs. ${ }^{45}$

From September 1914 on, the CUP began drawing up formations of irregular brigands in order to invade Russia and Persia to provoke war. This secret military organization was integrated into the existing Special Organization (Teşkilât- $\iota$ Mahsusa). ${ }^{46}$ The cadre of these new guerrilla bands (çetes) was to be made up of convicts, Kurdish tribesmen, and Muslim immigrants, and they were to be led by the same gangsters the CUP had used in the Balkan wars and in prior political conflicts. The convicts, called "savages and criminals" even by CUP officials, ${ }^{47}$ were very often tribesmen, local outlaws, and bandits who had committed theft or manslaughter. According to an Ottoman bureaucrat, they were drilled in Istanbul for one week before being deployed in various regions. ${ }^{48}$ The entire operation was led by Dr. Bahaeddin Şakir and was kept out of the control of the Ottoman army as much as possible. ${ }^{49}$ On 18 November, Talât personally ordered the drawing up of lists of names of "those convicts who were able to exert influence on tribes."50 A week later, the Special Organization was put together in Diyarbekir. Among the members enlisted in the paramilitary organization was the Zaza brigand Alo, ${ }^{51}$ as well as the Chechen criminal Hamid and his group of loyal warriors. Hamid was recruited by CUP Responsible Secretaries who cabled the following notification to the Central Committee in Istanbul:

The courageous brigand Chechen Hamid, resident of the town of Reşadiye in the Bergama district, has requested help to assist the army with some of his comrades and if allowed, form a significant corps in Diyarbekir. Since we hope that aforementioned gentleman is able to serve in this way, their dispatch will benefit the homeland. We would like to request a telegraphic answer on whether their patriotic venture will be necessary or not, and present our compliments, dear brothers. ${ }^{52}$

During the winter of 1914, the brigands began penetrating into Russian and Persian territory to incite the Muslim populations to rise in rebellion and join the Ottoman 
forces. In this guerrilla war, Special Organization operatives such as Yenibahçeli Nail, Deli Halit, and Topal Osman also attacked Armenian villages, plundering, raping, and killing with impunity. Ambassador Wangenheim wrote to the German chancellor that their anti-Russian actions across the Erzurum border frequently escalated into "encroachments and clashes" against Armenian villagers. ${ }^{53}$

The war on the eastern front gained momentum when warmonger Enver Pasha, driven by expansionist designs toward the east, on 29 December attempted to attack the Russian army in Sarıkamış. Enver insisted on waging an encirclement campaign through the rugged Kars mountains. However, the Russian general Nikolai Yudenich anticipated the outflanking maneuver, outsmarted Enver, and delivered a heavy blow to his forces. Enver's attack failed miserably, and as a result the Third Army was effectively wiped out. Of the 90,000 soldiers who fought in the battle of Sarıkamış, approximately 78,000 perished, mainly through frostbite. ${ }^{54}$ The CUP leadership was convinced that the disastrous defeat had been caused by "treacherous Armenian elements." Retreating Ottoman soldiers took revenge on Armenian villagers, massacring many and pillaging their goods. After returning from the front, Enver wrote a letter to the Armenian prelate of Konya, expressing his respect and admiration for the courage the Armenian soldiers had shown in the Sarıkamış battle. Enver gave the example of Sergeant Ohannes, who had received a medal for valor. ${ }^{55}$ This may not have been how Enver really felt. In a personal discussion with publisher Hüseyin Cahit, Enver bitterly blamed the Armenians for the fiasco and proposed their deportation to somewhere where they wouldn't cause trouble. ${ }^{56}$

The defeat triggered a new wave of persecution, especially in the front-line provinces of Erzurum, Bitlis, and Van. On 26 December 1914 Talât ordered "the dismissal of all Armenian police officers, police chiefs, and government employees, and the deportation of anyone who opposes these measures." 7 Talât Pasha's involvement in the dismissal of Armenian government officials typifies his "micromanaging" qualities. In February he urged local officials to keep him abreast of the developing situation with regard to Armenian civil servants. ${ }^{58}$ When he got the impression that the firings were not proceeding quickly enough, he personally had Police Chief Krikor and police officers Armenag, Boghos, and Shahin of the Van police squad removed from their offices and deported to Mosul. ${ }^{59}$ Finally, in November 1916 , the Interior Ministry issued an official declaration sanctioning the dismissal of all Armenian and Greek police officers. ${ }^{60}$ These official decrees marked an acceleration in CUP suspicion of Armenian loyalty to the Ottoman state.

For the population of Diyarbekir, there was little to celebrate between Christmas and New Year's Eve 1914. The news of Enver's losses reverberated in Diyarbekir and had a detrimental effect on local morale. The war was experienced closely and emotionally, since both Muslims and Christians had been drafted into the army and many of them had perished in the Sarıkamış campaign. The bad news distressed both communities and strained their relationships, sparking suspicion and enmity. The Church of Saint Ephraim was vandalized and property was stolen, while gendarmes beat up a Syriac village headman. ${ }^{61}$ The governor also prohibited the use of all non-Turkish languages in some of the province's institutions, such as the American hospital and the French mission. ${ }^{62}$ In February 1915 the government initiated arms searches in Christian houses in Diyarbekir. During these violent searches, the inhabitants were accused of treason and espionage and of hiding guns in secret arms stores. On 18 February, twelve young men of the large Syriac village of Qarabash were 
sentenced to death on charges of alleged desertion. Four of them were publicly hanged in the central square in Diyarbekir in order to deter potential deserters. ${ }^{63}$ When their compatriot villagers protested against the execution, gendarmes clubbed two men to death and dispersed the group. ${ }^{64}$

March also saw the disarming of Armenian soldiers and their recruitment, together with many other Christian men, into labor battalions. ${ }^{65}$ The cadre of these battalions were deemed disloyal elements, as an official decree proscribed them "at all costs" from taking up arms in the regular Ottoman army. ${ }^{66}$ The labor battalion conscripts were deployed in road construction under dire circumstances in and around Diyarbekir. Irrespective of weather conditions, every individual, including teenagers, was forced to carry a daily load of fifty-five kilograms. Each battalion was escorted by two dozen soldiers. Many conscripts in the labor battalions perished of exhaustion, exposure, and maltreatment. On 5 March 1915 a Syriac native of Diyarbekir, Abed Mshiho, was conscripted in a labor battalion numbering 1,100 men and assigned to work on the Diyarbekir-Aleppo road. According to his account, the maltreatments increased every other day, with bastinados and other beatings becoming commonplace, and the violence escalating into sporadic murders of individual conscripts by late March. ${ }^{67}$

March 1915 was perhaps the most fateful month for the future development of the Ottoman Empire in general and of Diyarbekir province in particular. The naval attacks upon the Dardanelles strait and the Russian move toward Van sowed panic in the hearts and minds of the CUP leaders. ${ }^{68}$ This reinforced their established fear of a nightmare scenario in which Armenian disloyalty would pave the way for an Allied incursion into Anatolia. This apocalyptic suspicion led to a series of meetings of the Central Committee in Istanbul in mid-March. As a result of these gatherings, Dr. Bahaeddin Şakir was delegated substantial authority to deal with "the inner enemies." The Special Organization was reorganized, expanded, and placed under his jurisdiction. ${ }^{69}$ The army was given more autonomy, on Talât's orders, to "turn to the Third Army for the application of measures aimed at Armenian actions." ${ }^{\text {N0 }}$ Not much later, Talât imposed total censorship on the Armenian newspaper Azadamart and sent Osman Bedri, police commissioner of Constantinople, to confiscate their presses. ${ }^{71}$ This radicalization at the center metastasized to the periphery as Diyarbekir saw the appointment of its new governor: Dr. Mehmed Reşid.

\section{Center and Periphery: Minister Talât vs. Governor Reșid}

On 25 March 1915 the governor of Diyarbekir, Hamid Bey, was relieved of his duties and replaced by Dr. Reşid. Mehmed Reşid (Şahingiray) was born in a Circassian family in Russian Caucasia on 8 February 1873. When the czarist government intensified its campaign against the Circassians in 1874, his family fled to the Ottoman Empire. Reşid grew up in Istanbul, where he enrolled in the Military School of Medicine and joined other students to found the kernel of a secret political party that would later adopt the name CUP. In 1897 the Abdulhamid regime exiled him to Tripoli for his politically recalcitrant activities. Having made a career in the army and risen to the rank of major, he wrote a book on the CUP revolution in 1908. He was never influential in the CUP core, however, and his power did not compare to that of party bosses such as Dr. Bahaeddin Şakir or Dr. Nâzım. In 1909 he relinquished his employment in the military and went on to serve as district governor and mayor in several provinces between 1908 and 1914. Along his professional path Reşid gradually radicalized and scapegoated Christians as the reason for the empire's erosion and wretched condition. 
By 1914 he was thoroughly convinced that the Ottoman Christians were abusing their ostensibly privileged position and were thus to blame for the empire's depressed economy. He was delegated the task of secretary-general of the international reform plan for the eastern provinces, which was annulled when the CUP engaged in war. In 1915 he became governor of Diyarbekir, and in 1916 he was appointed governor of Ankara. When the war was over, he was arrested and incarcerated in Istanbul. With the assistance of his former henchmen, he escaped from prison and lived incognito at various Istanbul addresses. Fed up with being forced to evade the law, and fearing arrest and possible execution, he committed suicide when a police chief tracked him down on 6 February 1919. ${ }^{72}$

When Reşid acceded to the governorship of Diyarbekir province, he brought with him thirty, mainly Circassian, Special Organization operatives, including Çerkez Harun, Çerkez Şakir, and Çerkez Aziz. ${ }^{73}$ They were joined in Diyarbekir by more troops released from the local prison. ${ }^{74}$ In this way, Reşid absorbed more effective power than the average Ottoman governor. For Reşid, it was certainly true that "in the provinces party bosses of one kind or another often exercised substantial control, amounting in some cases, [...] to virtual autonomy." "75 Upon arrival in Diyarbekir, Reşid and his men faced poor rule of law, a serious desertion problem, and an anxious population. The bazaar, for example, was buzzing with rumors that the Russians had invaded Istanbul. ${ }^{76}$ The Muslims feared an invasion of Diyarbekir by the Russian army, whose reputation as a valiant fighting corps had preceded its offensive into the south. The Christians were torn between fear and hope: whereas one moderate group (including the clergy) was terrified that a Russian incursion might trigger reprisals, another, discordant group (notably Armenian nationalists) expressed the audacious belief that it was possible for Christians to defend themselves against the brutal policies of the CUP dictatorship. ${ }^{77}$

The concerns of many young men were of a more pragmatic nature. They wanted to avoid the possibility of being conscripted into the Ottoman army and sent off to an almost certain death, either at the front or in the labor battalions. Therefore, some had actually gone into hiding in the complex web of rooftops of Xançepek, a neighborhood with a large concentration of Armenians. Some of these draft evaders had acquired weapons. ${ }^{78}$ Dr. Floyd Smith, an American doctor on the American Board of Commissioners for Foreign Missions (ABCFM), reported that at the end of February, the Armenian bishop Tchilgadian finally "went upon the roofs and lectured the men, telling them that they were bringing ruin upon themselves and the whole Christian

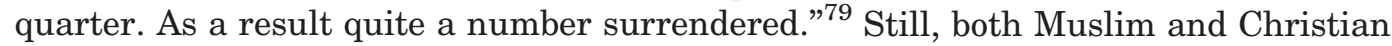
deserters remained when Dr. Reşid became governor.

In a post-war booklet titled Mülâhazât ("Reflections"), ${ }^{80}$ Reşid defended and sought to legitimize his wartime policies as governor of Diyarbekir. These memoirs, composed of two of his four wartime notebooks (the other two were lost), are of extraordinary importance, as they allow a close look at his line of thought when he was appointed governor. From the moment he set foot in Diyarbekir, Reşid found confirmation of his expectations of a conspiracy of disloyal Christians. He wrote,

My appointment to Diyarbekir coincided with a very delicate period of the war. Large parts of Van and Bitlis had been invaded by the enemy, deserters were transgressing, pillaging and robbing everywhere. Yezidi and Nestorian uprisings in or at the border of the province required the application of drastic measures. The transgressive, offensive and impudent attitude of the Armenians was seriously endangering the honor of the government. $^{81}$ 
In his memoirs Reşid especially targets the Armenians, accusing them of "high treason" (hıyânet-ı vataniye) and of "pursuing the goal of an independent Armenia" (müstakil bir Ermenistan gayesini takib). ${ }^{82}$ In his paranoia and animosity Reşid ignored the many Muslim deserters and imagined an army of Armenian deserters, who in fact may not have been as countless and organized as he visualized. He believed that the Armenian draft dodgers on the rooftops were all "formidably" (müdhiş) organized revolutionaries and that they numbered more than a thousand. Furthermore, according to Reşid, "there was not a single Armenian in the province who was not participating in this national endeavor." 83

In order to deal with these perceived problems, Reşid organized a committee for the "solution of the Armenian question." This council was called the Committee of Inquiry (Tahkik Heyeti) and had its own Militia Unit (Milis Alayı) at its disposal. ${ }^{84}$ According to a German charity worker, the committee, made up of a dozen CUP loyalists, was "a sham committee for the solution of the Armenian Question" and served only one purpose: to eliminate the Hunchak and Dashnak parties. ${ }^{85}$ It was headed by Colonel Mustafa Bey (Cemilpaşazâde) and consisted of deputy Aziz Feyzi; postal clerk İbrahim Bedreddin; ${ }^{86}$ Majors Rüşdü Bey and Yasinzâde Şevki (Ekinci); the latter's brother Yasinzâde Yahya (Ekinci); representative of the Directorate for the Settlement of Tribes and Immigrants (İskân-ı Aşâir ve Muhacirîn Müdüriyeti, or IAMM) and director of the Diyarbekir branch of the Society for National Defense (Müdafaa- $\iota$ Milliye Cemiyeti) Veli Necdet; police chief Memduh Bey; militia commander Şevki Bey; and Şeref Uluğ, son of the mufti. ${ }^{87}$ On Reşid's orders, they selected the following civilians and appointed them to the rank of captain: Zazazâde Hacı Süleyman (by profession, a Zaza butcher in the Diyarbekir bazaar); Halil (also a butcher); Cercisaşazâde Abdülkerim; Direkçizâde Tahir; and Pirinççizâde Sıdkı (Tarancı). The following volunteers were nominated to the rank of lieutenant: Halifezâde Salih, Ganizâde Servet (Akkaynak), Muhtarzâde Salih, Şeyhzâde Kadri (Demiray), Pirânîzâde Kemal (Önen), Yazıcızâde Kemal, Zaza Alo Efendi, and Hacı Bakır. ${ }^{88}$

At that time, a certain Hacı Zeki of Lice, a fanatical activist, incited the locals of Mardin to take up arms against the Christians. Zeki convened groups of Muslims at his house in Mardin city, where he made inflammatory political speeches, openly calling for pogroms. The district governor of Mardin, a moderate man by the name of Hilmi, was displeased by Zeki's aggressive vilification. Since the outbreak of the war Hilmi had shown consistent efforts to restrain conflict and to maintain relative stability and moderate rule. He reprehended Zeki and expelled him from Mardin. Zeki then took off to Diyarbekir, where he found willing partners among the CUP elite who were just consolidating their rule in the provincial capital. ${ }^{89}$ On 6 April 1915 Talât ordered Reşid to "appoint a capable, loyal, and devout Ittihadist for the vacant position of mayor" in Diyarbekir. ${ }^{90}$ Reşid immediately fired the relatively mild Cemilpaşazâde Dr. Fuad Bey and replaced him with the rabidly anti-Armenian Sidkı. ${ }^{91}$ Police chief Dersimli Hüseyin Bey was replaced by IAMM boss Veli Necdet, who had previously occupied the office of provincial secretary. ${ }^{92}$ All the key positions in Diyarbekir were now occupied by CUP loyalists.

In Diyarbekir, Reşid now embarked on a relentless campaign to find and punish deserters. On 1 April he issued a proclamation demanding the surrender of all arms to the police. ${ }^{93}$ When this failed to produce the results he had expected, he intensified the arms searches from 5 April on. Aided by his gendarmerie commander, Major Rüşdü, he personally supervised and participated in the warrantless searches of churches and houses. ${ }^{94}$ While district governor Hilmi in Mardin visited the Christian 
clergy to congratulate them on Easter, ${ }^{95}$ Reşid's roundups of Armenian men became more and more arbitrary and categorical. As he wrote, "On a certain day I had the three or four most important streets in the Armenian neighborhood barricaded and ordered surprise searches on every single house in the early morning, arresting more than 500 armed deserters." ${ }^{66}$ By 15 April Reşid had already had more than 600 Armenian notables and artisans arrested and put in jail. There he had them tortured to exact confessions on the locations of hidden arms depots. The prisoners were beaten and burned with hot irons, had their nails pulled out with pliers, and suffered prolonged bastinado. ${ }^{97}$ Even so, Reşid was not satisfied with what had been accomplished and wired Istanbul twice to request the deployment of more manpower to assist his force of 300 gendarmes and policemen. The Interior Ministry did not comply with his requests, frustrating and galvanizing him into more severe measures. ${ }^{98}$

\section{The Cultural Side of Persecution: Book Burnings}

Heinrich Heine's drama Almansor contains a passage in which a fifteenth-century Spanish Muslim named Hassan, upon witnessing the burning of the Koran by Catholics, pronounces the following sentence: "That was only a prelude: there where books are burned, ultimately people are burned." The destruction of books considered hostile cultural property seems to be a feature of practically all state-sponsored violence. A peculiar aspect of the operation in the Ottoman Empire was the hunt for "recalcitrant" books and other texts, generally written in non-Ottoman languages. In Ottoman political jargon, unpatriotic material was branded "harmful documents" (evrâk-ı muzırre $)^{99}$ and had to be dealt with through counter-propaganda or violence. During their nationalist rule, the CUP confiscated and destroyed an unknown but undoubtedly large number of non-Turkish-language works.

The example of the dismissal of Ottoman Armenian government officials demonstrates Talât's close involvement in the supervisory process of the antiArmenian persecutions. It is therefore not surprising to come across evidence of his micromanaging, with surgical precision, the bureaucratic excision of Armenian culture from Ottoman society. A striking example is the fate of the books in the library of the Armenian lyceum of Sivas. In October 1916 Talât was disturbed by the idea that the library kept "important volumes on the condition of the Ottoman Empire in French, German, English, Russian, and Kurdish," and he ordered "the immediate seizure of these books and their dispatch to Istanbul by post." ${ }^{00}$ Five months later, when the books still had not been sent, he repeated his order, requesting that the books be sent "urgently."101 Although one can only speculate as to the fate of these books, examples from Diyarbekir province demonstrate that it is most likely they were destroyed.

In Diyarbekir it was common for the authorities to target and destroy books. As Floyd Smith wrote, "Books and papers were sure to bring condemnation to a household."102 On 22 April Reşid's men went from door to door in the Xançepek and Fatihpaşa neighborhoods to find books. The Syriac tailor Habib had warned the inhabitants to hide their books, especially books in the French and Armenian languages. The militia also paid a visit to the Armenian bishop Tchilgadian and accused him of hiding arms in secret niches in the large Armenian church of St. Sarkis. They raided his room, took away all his books and documents, and sent them to Reşid for examination. The next day the books were publicly burned. ${ }^{103}$ Vahram Dadrian was a young boy keeping a diary when he was deported with his family from Çorum. After many trials and tribulations, they arrived in the Syrian 
desert and met an Armenian man named Pakrad, who had just escaped from Diyarbekir. Pakrad told them that his father, Abraham, had been caught up in the book searches. A corporal took two of their books and walked out of the house, facing a frantic crowd of Muslims:

The corporal gestured to the crowd to shut up. "Listen! Look here. Look what we found in his home," he yelled, lifting a geography book into the air. "You don't know how to read, so you don't know how dangerous this book is. But I won't have to say much before you can draw your own conclusions. In the hands of our enemies this book is a more terrifying weapon than all the guns and cannons of the army. This book gives the locations of all the cities, villages, rivers, and roads in Turkey. All of them meticulously portrayed. Anybody who goes through this book can find not only the plan of every city, but also the location of every house and whether it belongs to a Christian or a Muslim. They have marked each one with a cross or a crescent, so that one day when they rebel it will be easy for them to tell a Muslim household from the others." Grumbling from the mob-arms into the air in defiance! "Oh, oh, oh ... clobber him, kill him, let him rot, the traitor." "Please, calm down. Not so fast," the corporal ordered with authority, "I haven't finished yet. Look. Here's another book." He held up another book-a physics text. "It tells you all you need to know about how to make gun-powder, bullets, and dynamite. These conspirators' homes are filled with books like this. Both the young and the old read these books and learn what to do to destroy our country. But thank God and the Sultan that we have been vigilant and were able to uncover their plot at the last minute. Now it's we who will destroy their homes and put their children to the sword." The policemen had a hard time clearing a way through the violent crowd. They finally succeeded and, pulling and pushing their victim, they took him off to jail. ${ }^{104}$

Together with other owners of targeted books, Pakrad's father Abraham died in jail, where the chances of either escape or survival were very slim.

One of many examples of book burnings during the Armenian Genocide is the destruction in July 1915 of the library of Addai Sher, the Chaldean Bishop of Siirt, which contained thousands of books. ${ }^{105}$ The library of the Saint John Church in Mardin was also confiscated ${ }^{106}$ and the books given away to stores in Mardin or sold for practically nothing. ${ }^{107}$ A teacher at the Syriac monastery of Deyrulzaferan noted in his memoirs that, thanks to the government's carte blanche to certain Kurdish tribes to attack Christians, the other important Syriac monastery, Mor Gabriel, was attacked in the fall of 1917 by the Kurdish brigand Şendi, who massacred inhabitants and destroyed the library. ${ }^{108}$ However, attacks on books and libraries were generally coordinated by the government. In the 1920s, Hasan Reşit (Tankut) oversaw the confiscation of "many books written in foreign languages," including minority languages such as Kurmanci, Zazaki, Syriac, and Arabic, during the post-war campaign to continue homogenizing Anatolia. ${ }^{109}$ Government agents often stumbled over books when dealing with recalcitrant elements. When Alişêr, a Kurdish chieftain-poet famous for inciting the Eastern Kizilbash population against the authorities, was killed, a coffer of his books was confiscated by the Kemalists. ${ }^{110}$

\section{Targeting the Elite and Experimenting with Mass Violence}

In late April, the Diyarbekir city prison was swarming with prisoners. Reşid ordered the large caravanserai of Diyarbekir evacuated, as every day several dozens of prisoners were locked up and tortured in that khan. ${ }^{111}$ But these violent persecutions were not limited to Diyarbekir. In April a gradual shift occurred from discerning 
between combatants and non-combatants to not differentiating them anymore. This momentum is exemplified by the crucial battle of Van, which had very high stakes for all parties. The Van front saw mutual indiscriminate massacring of Muslims by the joint Russo-Armenian forces and of Christians by Ottoman forces. ${ }^{112}$ The antiArmenian measures at the national level now became more and more categorical as well. Moreover, inspired by the brutalizing war in Persian Azerbaijan and in Transcaucasia, they were also gaining "total" traits: more and more violence was applied to more and more people. Fear of Allied landings on the western coasts added fuel to the fire. As a result, the CUP began incarcerating dissidents and assailing the Armenian community all over the Ottoman Empire. Beginning on 24 April 1915, the political and cultural elite of the Ottoman Armenian community was targeted for arrest and deportation to the interior. With very few exceptions, these men were tortured to death over the next several months. Simultaneously, deportation convoys to the interior were rerouted to Der el-Zor in the Syrian desert. The persecutions soon increased in intensity and were extended to larger parts of the Ottoman Empire. ${ }^{113}$

In Diyarbekir, Reşid had not been distinguishing himself at all since his arrival. His intensive arms searches of the first three weeks of April had delivered some results for his militia, as, indeed, arms were found. The scope of armament and the extent of its organization were blown out of proportion, and photos were taken of the armaments and of the culprits. ${ }^{114}$ On 27 April Reşid wired an elated telegram to Talât summarizing and evaluating his work in Diyarbekir:

For ten days, the pursuit of deserters has been carried out with utmost severity. As a result of yesterday's purges a significant amount of explosives, fifty bombs, lots of ammunition and various arms, and a great deal of dynamite powder were found. One hundred and twenty leaders and operatives of the villages were taken into custody. Until now, in the city alone more than 1,000 deserters of different regions have been apprehended, many of whom are party members. Searches and pursuit are continuing. ${ }^{115}$

Having incarcerated the bulk of the political elite of the Diyarbekir Christians, Reşid's militia now targeted their religious leaders. Blanket arrests of priests and monks were carried out, and their houses were ransacked. In Mardin, where Reşid's persecutions had not yet taken hold, the news from Diyarbekir nevertheless caused fear. The Armenian Catholic bishop Ignatius Maloyan had become anxious about the worsening situation and seems to have written a letter to his co-religionists, lest something happen to him. Maloyan's letter urges his parish to remain calm and loyal to the government; he wrote, "Above all, never lose your faith in the holy trinity." The letter was sealed and entrusted to the Syriac Orthodox Bishop Gabriel Tabbuni on the first of May. ${ }^{116}$

While the war was raging with great intensity on the eastern front, the CUP began questioning the loyalty of the Ottoman Armenians even more. On 5 May 1915 Talât authorized the Third Army to disarm all Armenian gendarmes in Diyarbekir. ${ }^{117}$ This way, even loyal Armenians were categorized as disloyal and treated as such. The next day the Directorate for Employment and Supplies of the Ministry of Economy ordered all its offices to fire their Armenian staff and "deport those of whom it is necessary to areas where there are no Armenians." 118 Having already arrested these men in Diyarbekir, Reşid proceeded to persecute the city's clergy and extend the arrests to the villages. On 9 May he summoned the Chaldean priest Hanna Soha in Mardin to come to Diyarbekir for interrogation. Upon his arrival, 
the militia publicly maltreated him before killing him in broad daylight in the street. ${ }^{119}$ The absence of constraints in this murder emboldened the militia and triggered a new wave of arrests and violence, this time targeting the surrounding villages as well. The predominantly Christian villages of Kabiye, Qarabash, and Qatarbel, all situated on the plain of Diyarbekir, were subjected to brutal arms searches by Yasinzâde Yahya and Pirinççizâde Sıdkı between 10 and 20 May. The village men were tortured by bastinado, and dozens were taken away to the capital, filling the prison and the caravanserai. ${ }^{120}$ German charity worker Friedrich Schuchardt wrote that "between the 10th and 30th of May another 1,200 of the most notable Armenians and other Christians of Diyarbekir province were arrested without distinction between the religious denominations." ${ }^{21}$ Reșid then imposed the death penalty on any Armenian going outside the city walls. ${ }^{122}$ Diyarbekir had become an open-air prison and its Armenian neighborhood a de facto ghetto.

The persecutions also spread into the countryside, most notably to Mardin city, which was still ruled by Hilmi Bey, who had stalled and resisted anti-Christian persecutions in his district. On 15 May Reşid sent Aziz Feyzi to organize the round-up of the Christian elites of Mardin. During a secret meeting in which dozens of Muslim notables participated, a plan was laid out for the crackdown on the Mardin elite; however, this was practically impossible to carry out with Hilmi in office. ${ }^{123}$ Talât was still busy micromanaging the national persecution of the Armenian elite. On 19 May he ordered the Hunchak leader Paramas court-martialed in the Diyarbekir prison and inquired into the whereabouts of one Krikor Nalbandian. ${ }^{124}$ On 22 May he requested information on the Armenian politicians Agnouni and Rupen Zartarian, and their colleagues. $^{125}$

A critical event in Diyarbekir was the first large massacre involving the total destruction of entire village populations. On the morning of 20 May 1915 Reşid ordered Yahya and Sidkı to disarm Qarabash, a village just northeast of Diyarbekir. The village was invaded with fifty men and thoroughly disarmed; even bread knives were seized. Its men incarcerated, its weapons confiscated, Qarabash was now completely emasculated. That same evening Yahya and Sidkı visited neighboring Kurdish villages, inciting them to attack Qarabash and explicitly giving them fiat to plunder. Two days later, on 22 May, the village was invaded by mounted Kurds, who massacred its population with daggers, axes, and swords. Its two priests, Paulus and Behnam, were trampled to death under the horses' hooves. The women were raped, the houses were burnt, and valuables were seized. ${ }^{126}$ The few survivors fled to Diyarbekir, where some of them were treated by Floyd Smith. Smith reported the arrival of the Qarabash survivors as follows:

May 21, 1915, there came to our compound in Diarbekir from the village of Karabash, three hours to the east, three or four wounded and the following day (May 22) over a score of wounded Armenian and Syrian women and children. They, the villagers, told of a night attack by the Kurds three days previous and that the next morning the government had sent gendarmes who refused to allow anyone to come to Diarbekir. Some managed to get away and finally all who could walk or be carried came on the dates mentioned. The wounds were practically all infected and I have classified them as follows: [...]

(c) Wounds made by heavy cutting instruments, probably axes. [...]

2. Two children about seven and nine years and one woman; attempted decapitations. Deep incised wounds of the nape of the neck (just below the skull), 5-8 inches long and of a depth equal to the thickness of the muscles of this region. ${ }^{127}$ 
On that same evening, the 160 families of the village of Kabiye were targeted. ${ }^{128}$ The terrified villagers-some remaining men but mostly women, children, and the elderly-had taken refuge in the Mor Kiryakos church. Sidkı had persuaded Ömer, Mustafa, and Emîn, three sons of Perîxan, matriarch of the Reman tribe, to cooperate in the raid. They brought with them dozens of tribesmen, who combed the village for hemp rope to tie the men together. On Sidkı's orders, the men were tortured with hot iron pins, while women and girls were raped in the church. Within five hours, the militia and the tribesmen had hacked the villagers to death with axes. Many were crammed into haylofts and barns and burned alive. After the massacre, the Reman brothers loaded two saddlebags with money and gold and carried the goods away. ${ }^{129}$ The few survivors escaped to Diyarbekir, where some were killed by gendarmes. One woman stated that she survived the massacre "between the corpses of her relatives" (men bayn lashat herbo). When she fled to Diyarbekir city, a Zaza family proposed to take her into their home, but she refused out of fear. Another survivor, a boy, escaped death by hiding in a vineyard, which was overgrown by that time of the year. He was the only male survivor of the Kabiye massacre. ${ }^{130}$

\section{Five to Twelve: The Beginning of the End}

In April 1915, some Armenians had already been sporadically deported from their native regions, though this was not an empire-wide campaign. The deportation of the entire Armenian millet was officially organized from 23 May 1915 on, when Talât issued orders for the wholesale deportation of all Armenians to Deyr-ul Zor, starting with the northeastern provinces. ${ }^{131}$ That same day he urged the Fourth Army Command to court-martial any Muslim who collaborated with Christians. ${ }^{132}$ The Third Army had been put under the command of General Mahmud Kâmil Pasha, ${ }^{133}$ who had issued a similar order. His orders instructed "any Muslim who protected an Armenian hanged in front of his house, the burning of his house, his removal from office, and his appearance before a court-martial." ${ }^{134}$ These massive arrests and persecutions prompted the Entente Powers to make a joint declaration on 24 May, denouncing CUP policies against the Armenians. The declaration vehemently criticized these "new crimes of Turkey against humanity and civilization" and promised "that they will hold personally responsible... all members of the Ottoman government and those of their agents who are implicated in such massacres."135

The CUP leaders, especially Talât, panicked and attempted to disguise the deportations, requesting permission from the Grand Vizier on 26 May to issue a temporary deportation law. Although the deportations had already begun, the Grand Vizier endorsed Talât's law on 29 May, rushing the bill through Parliament the next day. This legislation gave a legal veneer to the official inception of the deportation of all Ottoman Armenians to the Syrian desert, authorizing the army to proceed with this project and delegating its daily implementation to the Directorate for the Settlement of Tribes and Immigrants. ${ }^{136}$

The Armenian Genocide had now officially begun.

\section{By Way of a Conclusion}

The persecution process of the Ottoman Armenians was an internal campaign that ran parallel to the external war effort with the Great Powers, especially on the eastern front against Russia. It was no coincidence that most of the direct killing of non-combatant Ottoman Christians would occur in the eastern provinces, where the 
threat of a Russian invasion backed by "Armenian insiders" was most immediate in the paranoid minds of the CUP dictatorship. However, the persecution was mostly an autonomous process and was only partly linked to the ebb and flow of the war. The initiation and conduct of the persecutions were in the hands of civilian bureaucrats in the Ministry of the Interior, not those of military personnel in the Ministry of War. The Ottoman province Diyarbekir has served as a platform for exemplifying these policies at the local level. The following two main arguments of this study may provide benchmarks for future research.

First, in the historiography of the Armenian Genocide, Talât Pasha's role has not yet received the attention it deserves. His role as a micromanaging dictator operating from the center crystallizes from a detailed inquiry into archival documents of the Ottoman Ministry of the Interior. From the most sweeping of categorical macromeasures to the micro-level dismissals of hundreds of individuals, Talât was very much personally involved in the persecution. The overall direction of Ottoman government policies toward Armenians may seem incongruous and contradictory at times, ${ }^{137}$ and more research on the nature of the CUP dictatorship would clarify this issue. The relationship between center and periphery can be illustrated by counterposing Talât's leverage as minister to Reşid's executive power as governor. In the period between January and April 1915 Talât ordered the surveillance of Armenians to be accelerated. Eager to satisfy his superior, the overachieving Reşid took local initiative and applied considerable overkill in dealing with the issues at stake. Once the governor began experimenting with wholesale killing and demonstrated its efficiency, he also transgressed a moral boundary. From then on, Talât would not hesitate long to authorize the expansion of murder from individuals to groups.

Second, the Armenian Genocide did not fall from a clear blue sky. As in all instances of genocidal violence, it is difficult to pinpoint the exact timing of the initiation of the mass violence. As Donald Bloxham has pointed out, the Armenian Genocide arose incrementally out of the mechanism of cumulative radicalization: local radicalization was conveyed back to Istanbul, which in turn triggered new phases of persecution. ${ }^{138}$ In other words, the output of the system was returned to its input in order to regulate further output. Therefore, it is practically impossible to speak of an absolute starting point. Nevertheless, two stages represent critical turning points in the entire process as points of no return: the general arrests of 24 April 1915 and the general deportation orders of 23 May 1915. Without these policy directives at the central level, the massive scale of the ensuing genocide would not have been reached.

\section{Notes}

1. Foremost in this radical faction were Mehmet Talât (1874-1921), İsmail Enver (1881-1922), Dr. Bahaeddin Şakir (1877-1922), Dr. Nâzım (1872-1926), and others.

2. Norman Naimark, Fires of Hatred: Ethnic Cleansing in Twentieth-Century Europe (Cambridge, MA: Harvard University Press, 2001), 3-4.

3. Jacques Sémelin, Purifier et détruire: usages politiques des massacres et génocides (Paris: Seuil, 2005).

4. See, e.g., Karl A. Schleunes, The Twisted Road to Auschwitz: Nazi Policy toward German Jews, 1933-1939 (Urbana: University of Illinois Press, 1970); Yehuda Bauer, A History of the Holocaust (New York: Franklin Watts, 1982), esp. chapter 5, "The Evolution of Nazi Jewish Policy, 1933-1938”; John Mendelsohn, The Holocaust: Selected Documents in Eighteen Volumes, vol. 1: Legalizing the Holocaust: The Early Phase, 1933-1939

(New York: Garland Publishing, 1982); Saul Friedländer, Nazi Germany and the Jews, 
vol. 1: The Years of Persecution, 1933-1939 (New York: HarperCollins, 1997); Ton Zwaan, Civilisering en decivilisering: studies over staatsvorming en geweld, nationalisme en vervolging (Amsterdam: Boom, 2001), especially chapter 6, "De vervolging van de Joden in Duitsland, 1933-1939."

5. An exception to this is Roderic H. Davison, "The Armenian Crisis, 1912-1914," The American Historical Review 52 (1947): 481-505.

6. Mark Levene has dubbed this mechanism "post-genocide": Mark Levene, "The Changing Face of Mass Murder: Massacre, Genocide and Post-genocide," International Social Science Journal 174 (2002): 443-52.

7. Martin van Bruinessen, "The Ottoman Conquest of Diyarbekir and the Administrative Organisation of the Province in the 16th and 17th centuries," in Evliya Cyelebi in

Diyarbekir, ed. Martin van Bruinessen and Hendrik Boeschoten, 13-38 (Leiden: Brill, 1988); Alpay Bizbirlik, 16. yüzyll ortalarında Diyarbekir Beylerbeyliği’nde vakıflar (Ankara: Türk Tarih Kurumu, 2002); Nejat Göyünç, "Diyarbekir Beylerbeylişinin İlk İdari Taksimatı," Tarih Dergisi 22 (1969): 23-24.

8. İbrahim Yllmazçelik, XIX. yüzyılın ilk yarısında Diyarbakır (Ankara: Türk Tarih Kurumu, 1995); Abdulhalık Bakır, "Osmanlı Öncesinde Diyarbakır'da Sanayi ve Ticaret" (paper presented at the conference Oğuzlardan Osmanliya Diyarbakır, Dicle University, Diyarbakir, Turkey, 21 May 2004).

9. Hellmut Christoff, "Kurden und Armenier: Eine Untersuchung über die Abhängigkeit ihrer Lebensformen und Charakterentwicklung von der Landschaft" (Diss., University of Hamburg, 1935), 19-73.

10. Raymond H. Kévorkian and Paul B. Paboudjian, Les Arméniens dans l'Empire ottoman à la veille du génocide (Paris: Editions d'Art et d'Histoire, 1992), 392.

11. Martin van Bruinessen, Agha, Shaikh and State: The Social and Political Structures of Kurdistan (London: Zed, 1992), chapters 2-4.

12. Walther J. Fischel, "The Jews of Kurdistan a Hundred Years Ago: A Traveler's Record," Jewish Social Studies 6 (1944): 195-226; A. Medyalı, Kürdistanlı Yahudiler (Ankara: Berhem, 1992), 58; Erich Brauer, The Jews of Kurdistan (Detroit, MI: Wayne State University Press, 1993).

13. Ralph H.W. Empson, The Cult of the Peacock Angel: A Short Account of the Yezidi Tribes of Kurdistan (London: AMS Press, 1928).

14. Hans-Jürgen Sasse, "Linguistische Analyse des arabischen Dialekts der Mhallamiye in der Provinz Mardin (Südosttürkei)" (PhD diss., Ludwig-Maximilians University of München, 1970).

15. Hans Hollerweger, Turabdin (Linz: Freunde des Tur Abdin, 1999).

16. The study of early-twentieth-century Ottoman demography demands careful scrutiny, as it is not only difficult to produce concrete and reliable statistics, but also a political minefield in which contemporary and present-day nationalist scholarship plays a role. Kemal H. Karpat, Ottoman Population 1830-1914: Demographic and Social Characteristics (Madison: University of Wisconsin Press, 1985); Justin McCarthy, Muslims and Minorities: The Population of Ottoman Anatolia and the End of the Empire (New York: New York University Press, 1983); Levon Marashlian, Politics and Demography: Armenians, Turks, and Kurds in the Ottoman Empire (Cambridge, MA: Zoryan Institute, 1991).

17. For a critical assessment of these arguments see Rober Koptaş, "Armenian Political Thinking in the Second Constitutional Period: The Case of Krikor Zohrab" (MA thesis, Boğaziçi University, 2005), 12-15.

18. I have dealt with these delicate issues in greater detail in my MA thesis: see Uğur Ü. Üngör, “'A Reign of Terror’: CUP Rule in Diyarbekir Province, 1913-1923” (MA thesis, University of Amsterdam, 2005), 21-32.

19. Şevket Beysanoğlu, Ziyâ Gökalp'ın Illk Yazı Hayatı: 1894-1909 (Istanbul: Diyarbakır'ı Tanıtma Derneşi Neşriyatı, 1956), 11-12.

20. Until the Balkan wars, Gökalp compared Ottoman society to US society, as in both countries many different ethnic groups coexisted under one denomination (Ottoman 
and American, respectively). In fact, Gökalp even rejected Turkish ethnic nationalism, as it entailed nation building based on blood bonds, which he considered unreal.

Mehmed Mehdî, "Türklük ve Osmanlılık," Peyman II, quoted in Beysanolu, Ziyâ Gökalp'ın, 99-101, 105.

21. According to one researcher of the period, the Pirinççizâde dynasty owned thirty villages in the vicinity of Diyarbekir city. Malmîsanij [pseud.], Kürt Teavün ve Terakki Cemiyeti ve Gazetesi (Spånga, Sweden: Apec, 1998), 41.

22. Politisches Archiv Auswärtiges Amt [PAAA], R14084, Mutius to Bethmann Hollweg, 14 June 1914.

23. Tarık Zafer Tunaya, Türkiye'de Siyasal Partiler, vol.1 (Istanbul: İletişim, 1997), 600-601.

24. Jacques Rhétoré, "Les chrétiens aux bêtes! Souvenirs de la guerre sainte proclamée par les Turcs contre les chrétiens en 1915" (unpublished manuscript, Bibliothèque du Saulchoir), 59-60.

25. Vartkes Yeghiayan, ed., British Foreign Office Dossiers on Turkish War Criminals (Pasadena, CA: AAIC, 1991), 479. Given his reputation, Aziz Feyzi's assignment to Diyarbekir caused unrest and anxiety among Armenian politicians there. Gaïdz F. Minassian, "Les relations entre le Comité Union et Progrès et la Fédération Révolutionnaire Arménienne à la veille de la Premiere Guerre mondiale d'après les sources arméniennes," Revue d'histoire arménienne contemporaine 1 (1995): 45-99, 90, n. 27.

26. Yeghiayan, British Foreign Office Dossiers, 480.

27. As in CUP structures at the national level, many of these people were related to each other: Aziz Feyzi was both Ziyâ Gökalp's and Şeref's cousin, and Sıdkı was related to both of them on his maternal and paternal sides. Malmîsanij [pseud.], Kürt Teavün ve Terakki Cemiyeti ve Gazetesi (Spånga, Sweden: Apec, 1998), 41.

28. Kamal Madhar Ahmad, Kurdistan during the First World War, trans. Ali Maher Ibrahim (London: Saqi, 1994), 73.

29. Martin Gilbert, Winston S. Churchill, vol. 3, 1914-1916: The Challenge of War (Boston: Houghton Mifflin, 1971), 189.

30. Sergej D. Sazonov, Les années fatales: souvenirs de M.S. Sazonov, ancien ministre des Affaires étrangères de Russie (1910-1916) (Paris: Payot, 1927), 182.

31. Cemal Pasha, Hatıralar: Ittihat ve Terakki ve Birinci Dünyâ Savaşı Anıları (Istanbul: Çağdaş, 1977), 141. Unless otherwise noted, all translations into English are my own.

32. For the eight articles of this treaty, see Şevket S. Aydemir, Makedonya'dan Orta Asya'ya Enver Paşa, vol. 2 (1908-1914) (Istanbul: Remzi, 1972), 510.

33. Cemal Pasha, Hatıralar, 142-43.

34. Paul G. Halpern, A Naval History of World War I (Annapolis, MD: Naval Institute Press, 1994), 76.

35. John Keegan, The First World War (New York: Vintage, 1998), 217.

36. Başbakanlık Osmanlı Arşivi [BOA], DH.ŞFR 44/200, Talât to provinces, 6 September 1914.

37. In Parliament, CUP members had dubbed the capitulations "satanic angels." Meclisi Mebusan Zabit Ceridesi, 3rd election period, 4th sitting, 60th sess., 1028. In his memoirs Cemal Pasha confesses that they wanted to "tear them apart." Cemal Pasha, Hatıralar, 438. The annulment of the capitulations "was received euphorically as a military success." Tarık Zafer Tunaya, Türkiye'de Siyasal Partiler, vol. 3 (Istanbul: İletişim, 1997), 420.

38. "İmtiyazat-ı Ecnebiyenin (Kapitülasyon) İlgası Hakkında İrade-i seniyye," in Takvim-i Vekayi, no. 1938, 17 September 1914. Together with the capitulations, the reform plan for the eastern provinces, which Russia had designed in 1913 mainly to curb abuses against Christians, was also de facto cancelled. Jan van der Dussen, "The Westenenk File: The Question of Armenian Reforms in 1913-1914," Armenian Review 39 (1986): 1-46.

39. Feroz Ahmad, "Unionist Relations with the Greek, Armenian, and Jewish Communities of the Ottoman Empire, 1908-1914," in Christians and Jews in the Ottoman Empire: The Functioning of a Plural Society, vol. 1, The Central Lands, ed. Bernard Lewis and Benjamin Braude, 401-34 (New York: Holmes \& Meier, 1982), 424. 
40. The German word Gleichschaltung (literally "synchronization") is a typical Nazi euphemism and describes the process by which the Nazi regime successively established a system of authoritarian control and tight coordination over all aspects of society between 1933 and 1939. This process included the purification of the state bureaucracy through the removal of officials without National Socialist sympathies. Karl D. Bracher, "Stufe totalitärer Gleichschaltung: Die Befestigung der nationalsozialistischen Herrschaft," Vierteljahrshefte für Zeitgeschichte 4 (1956): 30-42; Volker Dahm, "Nationale Einheit und partikulare Vielfalt: Zur Frage der kulturpolitischen Gleichschaltung im Dritten Reich," Vierteljahrshefte für Zeitgeschichte 43 (1995): 221-66. I use this term not to associate the CUP regime with Nazi Germany but, rather, as a sociological concept that can serve as a comparative tool within the field of genocide studies: namely, the process of configuration and top-down purification of the state bureaucracy in order to exercise more power. This should be recognized and interpreted through the academic currency of terms such as Zeitgeist, ancien régime, and Gestalt, which are also used to describe similar phenomena in different societies and historical settings. Unlike the NSDAP, the CUP did not have enough time or power to prepare, implement, and consolidate this operation before the war; therefore, the Gleichschaltung of provincial bureaucracies was often carried out on an impromptu basis during the war.

41. Ali Emîrî, Osmanlı Vilâyât-ı Şarkîyyesi (Istanbul: Dâr-ul Hilâfe, 1918), 34.

42. Ishaq Armalto, Al-Qousara fi Nakabat an-Nasar, 2nd ed. (Beirut: Al-Sharfe Monastery, 1970). This detailed chronicle was written in 1919 in Arabic by the Syriac priest Ishaq Armalto and provides a very valuable account of Diyarbekir province before and during the war. It has recently been published in Swedish: Ishaq Armalto, De Kristnas Hemska Katastrofer: Osmanernas och Ung-turkarnas Folkmord i norra Mesopotamien 1895/1914-1918, trans. Ingvar Rydberg (Stockholm: Beth Froso Nsibin, 2005). I have used an unofficial Turkish translation by Turan Karataş (Sweden, 1993), 22.

43. Daniel Thom to William Peet, 16 August 1914, quoted in Hans-Lukas Kieser, Der verpasste Friede: Mission, Ethnie und Staat in den Ostprovinzen der Türkei 1839-1938 (Zurich: Chronos, 2000), 336.

44. BOA, DH.ŞFR 47/243, Talât to Diyarbekir, 28 November 1914.

45. Thomas Mugerditchian, Dikranagerdee Nahankee Tcharteru, Aganadesee Badmoutiun (Cairo: Djihanian, 1919). This book is alternately titled Dikranagerdee Nahankin Tcharteru yev Kurderou Kazanioutounneru (Cairo, 1919).

46. A Mil, "Umumi Harpte Teşkilâtı Mahsusa," serialized in Vakit, 2 October 1933-18 April 1934; republished as Arif Cemil (Denker), I. Dünya Savaşı’nda Teşkilât-ı Mahsusa (Istanbul: Arba, 1997).

47. Ibid., 196.

48. Ahmet Refik (Altınay), Kafkas Yollarında: İki Komite, İki Kıtal (1919; reprint, Istanbul: Temel, 1998), 157.

49. Denker, Teşkilât-ı Mahsusa, 236-38.

50. BOA, DH.ŞFR 47/70, Talât to provinces, 18 November 1914.

51. Tarihi Muhakeme (Istanbul: Kitaphane-i Sûdî, 1919), 14.

52. Quoted from internal CUP correspondence, 23 November 1914, in Tunaya, Türkiye'de Siyasal Partiler, vol. 3, 349.

53. PAAA, R14085, Wangenheim to Bethmann-Hollweg, 29 December 1914.

54. Edward J. Erickson, Ordered to Die: A History of the Ottoman Army in the First World War (Westport, CT: Greenwood Press, 2000), 51-74. For a detailed account of the Sarıkamış disaster see Alptekin Müderrisoğlu, Sarıkamış Dramı, 2 vols. (Istanbul: Kağtaş, 1997).

55. Johannes Lepsius, Der Todesgang des Armenischen Volkes: Bericht über das Schicksal des Armenischen Volkes in der Türkei während des Weltkrieges (Potsdam: Tempelverlag, 1919), 161-62. 
56. Hüseyin C. Yalçın, Siyasal Anılar (Istanbul: Türkiye İş Bankası Kültür Yayınları, 1976), 233.

57. BOA, DH.ŞFR 48/166, Talât to the provinces of Erzurum, Bitlis, and Van, 26 December 1914.

58. BOA, DH.ŞFR 50/3, Talât to the provinces of Erzurum, Van, and Bitlis, 14 February 1915.

59. BOA, DH.ŞFR 50/179, Talât to Van province, 6 March 1915.

60. BOA, DH.EUM.MEM 80/63, 21 November 1916.

61. Armalto, Al-Qousara, 26, 27.

62. Ibid., 26.

63. Abed Mshiho Na'man Qarabashi, Vergoten Bloed: Verhalen over de gruweldaden jegens Christenen in Turkije en over het leed dat hun in 1895 en in 1914-1918 is aangedaan, trans. George Toro and Amill Gorgis (Glanerbrug, The Netherlands: Bar Hebraeus, 2002), 60. This important diary was originally written in Aramaic under the title Dmo Zliho ("Shed Blood") by Na'man Qarabashi, a native of the village of Qarabash. During the war Qarabashi was a theology student at the Syriac monastery of Deyr-ul Zaferan. Along with Armalto's account, it is one of the very few survivor memoirs.

64. Armalto, Al-Qousara, 27.

65. Raymond Kévorkian, "Receuil de témoignages sur l'extermination des amele tabouri ou bataillons de soldats-ouvriers Arméniens de l'armée Ottomane pendant la première guerre mondiale," Revue d'histoire arménienne contemporaine 1 (1995): 289-303.

66. See the official order in Kâmuran Gürün, Ermeni Dosyası (Ankara: Bilgi, 1988), 276.

67. Qarabashi names nine Armenians who were led away and killed. Qarabashi, Dmo Zliho, $62,64-66$.

68. Should the Entente navy penetrate the Straits, Talât promised that the Ottomans would blow up the Aya Sofia and retreat into the Anatolian heartland, whence they planned to resist and repel the Entente. Talât laughed at US Ambassador Henry Morgenthau's protests, saying that not even six men in the CUP would care about the building. Henry Morgenthau, Ambassador Morgenthau's Story (Ann Arbor, MI: Gomidas, 2000), 132.

69. For a detailed reconstruction of this decision-making process, see Taner Akçam, Insan haklart ve Ermeni sorunu: Itttihat ve Terakki'den Kurtuluş Savaşı'na (Istanbul: İmge, 2001), 260-65, especially 264.

70. BOA, DH.ŞFR 51/15, Talât to the provinces of Erzurum, Van, and Diyarbekir, 14 March 1915.

71. Heinrich Vierbücher, Armenien 1915: Die Abschlachtung eines Kulturvolkes durch die Türken (1930; reprint, Bremen: Donat \& Temmen Verlag, 1985), 49.

72. Hans-Lukas Kieser, "Dr. Mehmed Reshid (1873-1919): A Political Doctor," in Der Völkermord an den Armeniern und die Shoah/The Armenian Genocide and the Shoah, ed. Hans-Lukas Kieser and Dominik J. Schaller, 245-80 (Zurich: Chronos, 2002).

73. Mehmed Reşid, Mülâhazât (Istanbul, 1919), transliterated in Nejdet Bilgi, Dr. Mehmed Reşid Şahingiray'ın hayatı ve hâtıraları (İzmir: Akademi, 1997), 89, n. 28. According to Abidin Nesimî, son of the then mayor of Lice, Hüseyin Nesimî, the number of volunteers Reşid employed was twenty. Abidin Nesimî, Yılların Iç̧inden (Istanbul: Gözlem, 1977), 39.

74. Yeghiayan, British Foreign Office Dossiers, 151.

75. Alexander L. Macfie, The End of the Ottoman Empire, 1908-1923 (London: Longman, 1998), 128.

76. Armalto, Al-Qousara, 28.

77. Ibid., 28 .

78. Mustafa Â. Tütenk, Mahsûl-i Leyâlî̀-i Hayatım (unpublished memoirs, Diyarbekir, 1918), fourth notebook, Diyarbekir'de Ermeni Hâdisesi [The Armenian Affair in Diyarbekir], 21-23, quoted in Şevket Beysanoğlu, Anıtları ve Kitabeleri ile Diyarbakır Tarihi (Diyarbakır: Diyarbakır Büyükehir Belediyesi Kültür ve Sanat Yayınları, 1996), 787-88.

79. Floyd Smith to James Barton, 18 September 1915, ABCFM Archives, Houghton Library (Harvard University), ABC 16.9.7, reel 716:436, quoted in Kieser, "Dr. Mehmed Reshid," 264. 
80. The booklet was alternately titled Sebat ("Persistence").

81. Reşid, Mülâhazât, 24.

82. Ibid., 95, 99.

83. Ibid., 103, 106.

84. Süleyman Nazif, "Doktor Reşid," in Hadisat, 8 February 1919. It is possible that the establishment of these provincial committees was an empire-wide undertaking. There is evidence that in other provinces similar organizations were set up: Yale University Library, Ernst Jäckh Papers, file 49, folio 1354, "Anlage Abschrift."

85. PAAA, R14087, director of the Deutscher Hülfsbund für christliches Liebeswerk im Orient (Frankfurt am Main), Friedrich Schuchardt, to the Auswärtiges Amt, 21 August 1915, encl. no. 6.

86. On 2 September 1914 İbrahim Bedreddin (Bedri for short) became the postal clerk of Diyarbekir province. Previously he had held this office in Basra and Mosul. After the Balkan wars of 1912-1913, he had coordinated the CUP-sponsored deportation of the Ottoman Greeks of Biga (a town between Çanakkale and Bursa). On 12 September 1915 he was officially appointed district governor of Mardin, which he remained until 11 December 1916. On 24 January 1917 he was assigned to the governorship of Diyarbekir, which he occupied until 24 November 1918. Yeghiayan, British Foreign Office Dossiers, 69-70.

87. A müftü (mufti) is a Muslim jurist who is versed in Islamic religious law (the shari'a) and provides binding advice on its application.

88. Beysanoğlu, Diyarbekir Tarihi, 793-94; Bilgi, Dr. Mehmed Reşid, 26-27. See also Joseph Naayem, Shall This Nation Die? (New York: Chaldean Rescue, 1921), 182-83. Reverend Naayem was a Chaldean priest of Urfa, where he witnessed the killing of his father and the persecution of the Christians. Disguised as a Bedouin Arab, he narrowly escaped with his life.

89. Armalto, Al-Qousara, 29, 34.

90. BOA, DH. ŞFR 51/220, Talât to Diyarbekir, 6 April 1915.

91. Reşid, Mülâhazât, 112. Immediately after the appointment of Sıdkı, a wave of violence swept over the labor battalions as two supervisors came to inspect the workers, yelling, "You're not here to play, come on, I want to see blood on those rocks!" Qarabashi, Dmo Zliho, 65.

92. Yeghiayan, British Foreign Office Dossiers, 48.

93. Floyd Smith to James Barton, 18 September 1915, quoted in Kieser, "Dr. Mehmed Reshid," 265.

94. Qarabashi, Dmo Zliho, 63.

95. Armalto, Al-Qousara, 29.

96. Reşid, Mülâhazât, 105.

97. Qarabashi, Dmo Zliho, 127. Fa'iz Al-Ghusayn, an Ottoman bureaucrat hailing from Damascus, was arrested for his opposition to the CUP and put in the Diyarbekir prison, where he witnessed the tortures inflicted on the Armenian notables. He later fled to Bombay and wrote his memoirs in Arabic. Fa'iz Al-Ghusayn, Martyred Armenia (London: C.A. Pearson, 1917).

98. Reşid, Mülâhazât, 103, 104.

99. BOA, ZB. 352/87, 18 June 1908.

100. BOA, DH.ŞFR 69/75, Talât to Sivas province, 23 October 1916.

101. BOA, DH.ŞFR 76/243-14, Talât to Sivas province, 24 May 1917.

102. Floyd Smith to James Barton, 18 September 1915, quoted in Kieser, "Dr. Mehmed Reshid," 264.

103. Armalto, Al-Qousara, 29. Patriarch Rahmani, 'Les dégâts causés à la nation syrienne' (presentation at the 1919 Peace Conference).

104. Vahram Dadrian, To the Desert: Pages from My Diary (London: Gomidas Institute, 2003), 64-65.

105. Addey Şer, Siirt Vakayinamesi, trans. Celal Kabadayı (Istanbul: Yaba, 2002), 8-9. 
106. Yves Ternon, ed., "Mardin 1915: Anatomie pathologique d'une destruction," special issue, Revue d'histoire arménienne contemporaine 4 (2002), 152.

107. Armalto, Al-Qousara, 105.

108. Abed Mshiho Na'man Qarabashi, Vergoten Bloed: Verhalen over de gruweldaden jegens Christenen in Turkije en over het leed dat hun in 1895 en in 1914-1918 is aangedaan (Glanerbrug, The Netherlands: Bar Hebraeus Yayınları, 2002), ss. 122-23.

109. "Türk Ocakları Altıncı Kurultayı," in Türk Yurdu 4/24, 29/223 (May 1930), 85, quoted in Füsun Üstel, Imparatorluktan Ulus-Devlete Türk Milliyetçilişi: Türk Ocaklart (1912-1931) (Istanbul: İletişim, 1997), 333.

110. Nazmi Sevgen, "Koçkirili Aliş," Tarih Dünyası 9 (1950): 377-83. In later years, too, the confiscation (and probable destruction) of books continued, and in a sense it continues today. Murat Belge, "Kitap yakmayı seven toplum," Radikal, 20 February 2005. For a comparative analysis of this phenomenon, see Rebecca Knuth, Libricide: The RegimeSponsored Destruction of Books and Libraries in the Twentieth Century (Westport, CT: Praeger, 2003).

111. Qarabashi, Dmo Zliho, 82, 128. This famous caravanserai, a large inn providing shelter to traveling businessmen or pilgrims, was also known as a "guest house" (misafirhane) or simply "khan" (han); it is presently known as the Deliller Hanı near the Mardin Gate. After restoration in the 1990s, it became the five-star Hotel Kervansaray.

112. Anahide Ter Minassian, "Van 1915," in Armenian Van/Vaspurakan, ed. Richard G. Hovannisian, 209-44 (Costa Mesa, CA: Mazda, 2000).

113. Donald Bloxham, "The Beginning of the Armenian Catastrophe: Comparative and Contextual Considerations," in Der Völkermord an den Armeniern und die Shoah/The Armenian Genocide and the Shoah, ed. Hans-Lukas Kieser and Dominik J. Schaller, 101-28 (Zurich: Chronos, 2002); Haig Tahta, April 1915 (London: Taderon Press, 2006).

114. Beysanoğlu, Diyarbekir Tarihi, 789. A similar method was applied in Mardin, where Memduh Bey had been sent. Ara Sarafian, "The Disasters of Mardin during the Persecutions of the Christians, Especially the Armenians, 1915," Haigazian Armenological Review 18 (1998): 262-93, 263.

115. Reşid to Talât, 27 April 1915, quoted in Hüsamettin Yıldırım, Rus-Türk-Ermeni Münasebetleri (1914-1918) (Ankara: KÖK, 1990), 57.

116. Armalto, Al-Qousara, 30.

117. BOA, DH.ŞFR 52/234, Talât to Reşid, 5 May 1915.

118. BOA, DH.ŞFR 52/249, 6 May 1915, Ministry of Economy to the provinces of Erzurum, Bitlis, Van, Sivas, Mamuret-ul Aziz, and Diyarbekir. Since there were no other educated clerks available, Syriac employees Aziz (son of Yakub) and George Meqdesi Nano of the Diyarbekir office of the Ministry of Economy were allowed to continue their work. The director of this office, Saib Ali Efendi, protected these two secretaries throughout the war. Armalto, Al-Qousara, 33. Most Armenian civil servants had already been fired and replaced by Muslims at that time. Some were still in office at the Ministry of Post. On 23 May this ministry too took action, ordering the dismissal of all its Armenian clerks and the transfer of the vacant functions to "trustworthy Muslims" (emin ve müslîm kimselere). BOA, DH.ŞFR 53/89, Ministry of Post to the provinces of Diyarbekir, Adana, Sivas, Ankara, Van, and Erzurum, 23 May 1915. For Haleb see BOA, DH.ŞFR 53/90. The following day, the ministry had to deal with the replacement of the Armenian postal clerk responsible for the delivery of mail beween Diyarbekir and Siirt. Although there were no other qualified employees available, it warned that the new postal clerk must not be an Armenian. BOA, DH.ŞFR 53/97, Ministry of Post to Bitlis, 24 May 1915.

119. Armalto, Al-Qousara, 32.

120. Qarabashi, Dmo Zliho, 81, 86, 92.

121. PAAA, R14087, director of the Deutscher Hülfsbund für christliches Liebeswerk im Orient (Frankfurt am Main) Friedrich Schuchardt to the Auswärtiges Amt, 21 August 1915, encl. no. 6. 
122. US National Archives, RG 59, 867.4016/77, Morgenthau to Secretary of State, 20 July 1915 (encl. no. 3), in United States Official Records on the Armenian Genocide 1915-1917, ed. Ara Sarafian (London: Gomidas Institute, 2004), 103.

123. Armalto, Al-Qousara, 33.

124. BOA, DH.ŞFR 53/58, 19 May 1915, Talât to Reşid.

125. BOA, DH.ŞFR 53/74, 22 May 1915, Talât to Reşid.

126. Qarabashi, Dmo Zliho, 81.

127. ABCFM Archives, Houghton Library, Harvard University, ABC 16.9.7, vol. 25d, doc. 485, Floyd Smith to James Barton, 20 September 1919, quoted in James Barton, ed., "Turkish Atrocities": Statements of American Missionaries on the Destruction of Christian Communities in Ottoman Turkey, 1915-1917 (Ann Arbor, MI: Gomidas Institute, 1998), 92.

128. In the $1960 \mathrm{~s}$, a professor of Semitic languages, Otto Jastrow, traveled to Diyarbekir and Beirut to conduct several very valuable interviews with survivors from many villages. Jastrow has uploaded these recordings to an online archive, http://semarch.uni-hd.de/ (accessed 15 February 2006) and transcribed them in Aramaic, Arabic, and German translation. For the Kabiye massacre see Otto Jastrow, ed., Die mesopotamisch-arabischen Qeltu-Dialekte, vol. 2, Volkskundliche Texte in Elf Dialekten (Wiesbaden:

Kommissionsverlag Franz Steiner GmbH, 1981), 309-71.

129. According to Qarabashi, the amount of money stolen was £150. Qarabashi, Dmo Zliho, 89.

130. Jastrow, Die mesopotamisch-arabischen, 310. Many survivors of the Christian villages of the plain fled to the city, but they were not received with open arms. Survivors and scared villagers came pouring into the churches. A girl survivor related that upon arrival at the Syriac Mother Mary Church, she was chased away at the door by a Syriac Orthodox priest, who cursed at her and did not even give her a morsel of bread. Ibid., 324-25. According to the son of an Armenian survivor from the village of Satıköy, this priest was B'shero Abu Tuma, who had also been forced by Reşid to act as an informer and to betray houses where Armenians were hidden. Interview with David Krikorian (aged seventy-five) from Satıköy, Diyarbekir province, conducted in Turkish in Amsterdam on 16 December 2004.

131. BOA, DH.ŞFR 53/91, 53/92, and 53/93, Talât to provinces, 23 May 1915. This is the single instance in which the empire-wide nature of the deportations is reflected in one order at the most central level.

132. BOA, DH.ŞFR 53/85, Talât to Cemal Pasha, 23 May 1915.

133. On 12 February 1915 Mahmud Kâmil replaced General Hafız Hakkı, who had died in a spotted typhus epidemic. Erickson, Ordered to Die, 104.

134. Takvim-i Vekâyi, no. 3540, 7.

135. Public Record Office, FO 371/2488/51010, 28 May 1915; US National Archives, RG 59, 867.4016/67, 29 May 1915.

136. BOA, MV 198/163, 30 May 1915.

137. The Turkification of the Ottoman medical community is a good example of this apparent contradiction: at the same time the Interior Ministry began persecuting and liquidating Armenian doctors, the War Ministry was trying to cope with a severe lack of medical staff for sick and wounded Ottoman soldiers at the front. This example of a self-destructive crisis situation is not easily caught in simple formulations. Part of the answer lies in the tension between Enver and Talât, each of whom had his own agenda: Enver's main concern was to win the war, whereas Talât most of all yearned to Turkify the country with all the coercive power he could muster.

138. Donald Bloxham, "The Armenian Genocide of 1915-1916: Cumulative Radicalization and the Development of a Destruction Policy," Past and Present 181 (2003): 141-91. 


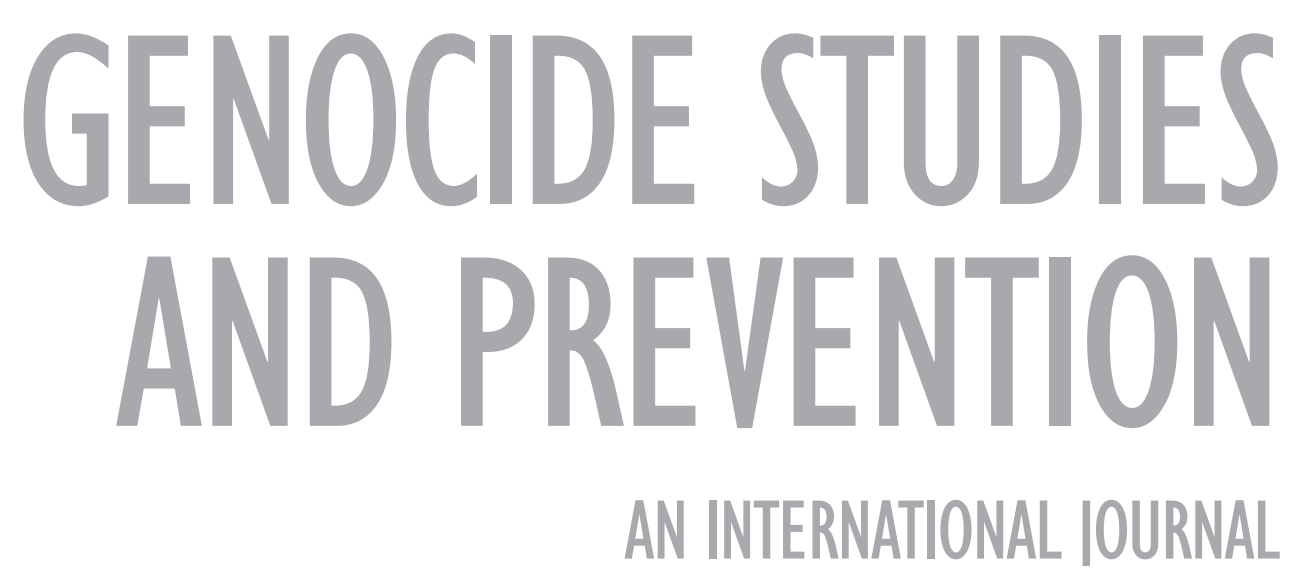

